\title{
Isolation of Bacteria with Purifying Potential and Application in the Treatment of Effluents from an Artisanal Palm Oil Mill in the Littoral Region of Cameroon
}

\author{
Djien Nyami Félicité1, Noubou Takam Daïna1, Fobasso Tagnikeu Roméoㄹ, Tcheugoue Styve Joël1, \\ Njicoumbe Fatima', Ndzobo Ndzana Joël' ${ }^{1}$, Kuessie Yanick ${ }^{1}$, Bella Josiane ${ }^{1}$, Foncha Felix ${ }^{2}$, \\ Emmanuel Mpondo Mpondo3 ${ }^{3}$ Véronique Penlap Beng ${ }^{4}$, Tavea Fréderic Marie ${ }^{1 *}$ \\ ${ }^{1}$ Department of Biochemistry, Faculty of Science, University of Douala, Douala, Cameroon \\ ${ }^{2}$ Institute of Agricultural Research for Development (IRAD), Yaounde, Cameroon \\ ${ }^{3}$ Department of Pharmaceutical Sciences, Faculty of Medicine and Pharmaceuticals Sciences, University of Douala, \\ Douala, Cameroun \\ ${ }^{4}$ Department of Biochemistry, Faculty of Science, University of Yaounde, Yaounde, Cameroon \\ Email: *trustfotaro@yahoo.fr
}

How to cite this paper: Félicité, D.N., Daïna, N.T., Roméo, F.T., Joël, T.S., Fatima, N., Joël, N.N., Yanick, K., Josiane, B., Felix, F., Mpondo, E.M., Beng, V.P. and Marie, T.F. (2021) Isolation of Bacteria with Purifying Potential and Application in the Treatment of Effluents from an Artisanal Palm Oil Mill in the Littoral Region of Cameroon. Journal of Environmental Protection, 12, 462-471.

https://doi.org/10.4236/jep.2021.127029

Received: April 11, 2021

Accepted: July 6, 2021

Published: July 9, 2021

Copyright $\odot 2021$ by author(s) and Scientific Research Publishing Inc. This work is licensed under the Creative Commons Attribution International License (CC BY 4.0).

http://creativecommons.org/licenses/by/4.0/ (c) (i) Open Access

\begin{abstract}
It is with the aim of solving the problem of generating large quantities of effluents from palm oil production in the littoral region of Cameroon that this study was carried out with the general objective of reducing the pollutant load of these effluents by using bacteria. To this end, raw palm oil mill wastewater samples were taken for their characterization by evaluating the in-situ (Temperature, $\mathrm{pH}$ and (CND) Conductivity) and ex-situ (SS (suspended solid), COD (chemical oxygen demand), BOD (biological oxygen demand) and $\mathrm{O} / \mathrm{F}$ (oil and fat)) parameters. In addition, bacterial isolation and screening were carried out from samples of contaminated soil based on the production of lipolytic enzymes, the degradation of oils and fats and the reduction of the pollutant load. Results revealed that 28 isolates were able to reduce the pollution parameters of palm oil mill effluents of which D17, D22 and D23 seemed to be the best purifying isolates. The characterization of the POME (palm oil mill effluent), basing the temperature, $\mathrm{pH}, \mathrm{CND}, \mathrm{O} / \mathrm{F}, \mathrm{SS}, \mathrm{BOD}$ and $\mathrm{COD}$ showed us values greater than the recommended rate. Partial characterization of these isolates revealed that D17 and D23 are bacteria that could reduce the polluting parameters of the effluents belonged to the Bacillus sp. genus and D22 to the Acinetobacter sp. genus. These results are satisfactory and the bacteria strains obtained could be used in bioremediation.
\end{abstract}




\section{Keywords}

Palm Oil, Mill Effluent, Bacteria, Pollution, Cameroon

\section{Introduction}

Water pollution is defined as the degradation of water by altering its natural, physical, chemical and biological properties. It thus disrupts the living conditions of aquatic flora and fauna [1]. To mitigate these negative impacts, it is necessary to put in place methods of treating water before it is discharged or reused for agricultural purposes. Treating wastewater before it is released into the environment is a major challenge for many countries around the world. This difficulty is more accentuated in developing countries which mainly suffer from a lack of capital [2]. This lack of wastewater sanitation has environmental (eutrophication, spread of bad odors), health (development of water-borne diseases) and economic consequences (loss of income for tourism and the high costs of water-borne disease care) [3]. Among the many industrial products likely to play the role of polluting agents, oils and fats constitute a major pollution problem. Vegetable oil mills are characterized by the use of large amounts of water and therefore produce effluents containing high concentration of fat. This poses a real environmental problem because they can behave like hydrocarbons and reduce the passage of oxygen, thus causing the clogging of pipes and the suffocation of aquatic living beings. The addition of microbial lipases and/or the culture of lipase-producing microorganisms in these effluents make it possible to reduce the lipid load and therefore the pollutant load [4]. Palm oil has an annual global production of 50 million tonnes with increasing annual production in Cameroon of 230,000 tonnes in 2010 [5]. Its production generates large quantities of effluents with a high concentration of oil and fat. The natural phenomenon of self-purification cannot therefore by itself achieve a significant reduction in this pollutant load [6]. It is, therefore, necessary to put in place an effective treatment strategy for the wastewater from these oil mills. The treatment of vegetable waters has been tested using several techniques (forced evaporation [7], coagulation-flocculation [8] [9], electro-coagulation [10] [11], aerobic treatment [12], anaerobic treatment [12] [13] and advanced oxidation [14] [15] [16] [17]). In Cameroon, very little work has been carried out by combining a sand filter and a bacterial bed (bacteria isolated from soils contaminated by the latter).

\section{Material and Methods}

\subsection{Characterization of Palm Oil Mill Effluents (POME)}

Samples of effluents from a crude palm oil mill were carried out between November 2020 and January 2021 in the Littoral region of Cameroon. Samples were taken in sterile $1 \mathrm{~L}$ bottles. Before the actual sampling, the bottles were washed 
three times with the effluent to be sampled in order to maintain the representativeness of the natural environment. All the analyzes and measures necessary to assess the pollution of these waters are governed by Cameroonian standards. In-situ parameters measured were $\mathrm{pH}$, temperature and electrical conductivity. Parameters analyzed in the laboratory were Chemical Oxygen Demand (COD), biochemical oxygen demand (BOD), suspended solids (SS), total nitrogen (TN), total phosphorus (TP) and oils and fats.

Temperature, $\mathrm{pH}$ and conductivity were measured at the site using a multi-parameter brand Combo HI 98130 from HANNA, instruments equipped with a probe. COD was determined by the "reactor digestion" method [18], the suspended solids (SS) were determined by filtering a volume of wastewater through a cellulose filter (mesh size $0.45 \mu \mathrm{m}$ ) [19]. Biochemical oxygen demand (BOD) was determined by "manometric" method using a WTW brand BOD5 incubator. Oils and fats $(\mathrm{O} / \mathrm{F})$ were determined by extracting lipids in a separatory funnel. A volume of $40 \mathrm{ml}$ of crude effluent is mixed with $40 \mathrm{ml}$ of $\mathrm{n}$-hexane for 2 minutes. This extraction is carried out twice in a row. The hexane phase is evaporated using a rotary evaporator under vacuum at a temperature of $100^{\circ} \mathrm{C}$. The tared flask is cooled, and the fat was determined by weighing [20]. The Kjeldahl nitrogen content or even total nitrogen consisting of organic and ammoniacal nitrogen was determined by the Kjeldahl method; Le total phosphorus (TP) is the sum of inorganic phosphorus and organic phosphorus. It was determined after mineralization of the sample [21] by "molybdovanadate" method.

\subsection{Isolation of Bacteria with Purifying Characteristics}

Soil samples were collected using a sterile spatula $0-15 \mathrm{~cm}$ deep from the soil polluted with POME. The fermentation medium consisted of $0.5 \%(\mathrm{~m} / \mathrm{v})$ peptone; $0.02 \%(\mathrm{~m} / \mathrm{v}) \mathrm{MgSO}_{4} ; 0.3 \% \mathrm{NaCl} ; 0.1 \%(\mathrm{~m} / \mathrm{v}) \mathrm{KH}_{2} \mathrm{P}_{4} ; 0.5 \%(\mathrm{v} / \mathrm{v})$ olive oil; $0.05 \%(\mathrm{v} / \mathrm{v})$ of tween 80 to emulsify. The whole was dissolved in distilled water and the $\mathrm{pH}$ of the medium was adjusted to 8 by adding $0.3 \%(\mathrm{~m} / \mathrm{v})$ of $\mathrm{Na}_{2} \mathrm{CO}_{3}$. The medium was sterilized at $121^{\circ} \mathrm{C}$ for 20 minutes. Once the medium has cooled, the stock solution is obtained after incubation at $30^{\circ} \mathrm{C}$ for 24 hours with $5 \mathrm{~g}$ of soil in $25 \mathrm{ml}$ of fermentation medium.

The isolation medium had the same composition as the liquid medium in the presence of bacteriological agar. After incubation, the fermented solution was subjected to decimal dilutions and 5 microliters of each fraction were seeded on the surface in Petri dishes according to the protocol used by Fobasso et al., In 2019 [22] then incubated at $30^{\circ} \mathrm{C}$ for 24 hours. Isolates obtained were individually taken and sub-cultured by the streak method on agar medium and incubated at $30^{\circ} \mathrm{C}$ for 24 hours. This operation was repeated until the pure isolates were obtained. Subsequently, these were stored at $4^{\circ} \mathrm{C}$ for subsequent analyzes. Regular sub-cultures of isolates were performed every two weeks [23].

\subsection{Screening of the Best Purifying Isolate}

Selecting criteria of the best purifying isolate were based on the relative purifying 
performance. The efficacy of each isolate was determined by characterization of the effluent (COD and O/F) before and after fermentation. For this purpose, $3 \mathrm{~L}$ of effluent were sterilized at $121^{\circ} \mathrm{C}$ for 20 minutes then $60 \mathrm{ml}$ were distributed in sterile $100 \mathrm{ml}$ flasks according to the protocol used by Suseela and Muralidhar in 2018 [24]. Eight percent (8\%) of each inoculum containing 106 cells/mL with an optical density of 1.2 at $600 \mathrm{~nm}$ was inoculated and then incubated at $30^{\circ} \mathrm{C}$ for 5 days with stirring at $150 \mathrm{rpm}$ in the presence of blank.

A bacterial isolate is more effective when it can further reduce the pollutant load present in the effluent. The purification yield was assessed analytically by monitoring the reduction rate of $\mathrm{COD}$ and $\mathrm{O} / \mathrm{F}$ [25]. The calculation of the reduction rate expressed as a percentage was therefore based on the following formula:

$$
\text { Reduction }(\%)=100-\left[\frac{\text { Craw POME }- \text { Cf }}{\text { Craw POME }} \times 100\right]
$$

\subsection{Partial Characterization of the Best Purifying Isolates}

It consisted in partially characterizing the best purifying isolates of our effluents through several tests, namely: phenotypic tests (macroscopic and microscopic identification) and biochemical tests (catalase test).

\section{Results and Discussion}

\subsection{Characterization of Palm Oil Mill Effluents (POME)}

Analysis of the palm oil mills effluent were carried out during the months of November, December (2020) and January 2021 because these are periods of dry seasons in Cameroon when the production of palm oil is very high. During this period, 3 samples at a rate of one sample per month were carried out for the crude effluents.

The palm mill effluents collected were brown in color, oily and bad smelling. The samples had high COD concentrations of 54,960 mg/L, SS of 65,015 \pm 2333.8 , $\mathrm{BOD}$ of $2373.3 \pm 262 \mathrm{mg} / \mathrm{L}, \mathrm{O} / \mathrm{F}$ of $605 \pm 32.5 \mathrm{mg} / \mathrm{L}$, an NDT of $4.6 \pm 0.4 \mu \mathrm{S} / \mathrm{cm}$, a $\mathrm{pH}$ of $4.9 \pm 0.4$, and a temperature of $51.8^{\circ} \mathrm{C} \pm 1.74^{\circ} \mathrm{C}$. These values are presented in Table 1 and show that these effluents are highly polluting for the environment. The chemical oxygen demand (COD) and biological oxygen demand $\left(\mathrm{BOD}_{5}\right)$ wich are the most used polluting parameters were $54,960 \pm 11,308.1 \mathrm{mg} / \mathrm{L}$ and $2373.33 \pm 2623.077 \mathrm{mg} / \mathrm{L}$ respectively. $\mathrm{COD}$ and $\mathrm{BOD}_{5}$ values obtained during this study are similar to those obtained by Najafpour et al. (2006) [26], Alhaji et al. (2016) [27] and Nur et al. (2017) [28]. However, Jeremiah et al. (2014) [25] and Suseela and Muralidhar (2018) [24] obtained higher values. Also, the concentrations of $\mathrm{O} / \mathrm{F}(605 \pm 32.5 \mathrm{mg} / \mathrm{L})$ obtained are similar to those obtained by Najafpour et al. (2006) [26], and Abdulkarim et al. (2011) [29]. These values are greater than those obtained by Suseela and Muralidhar (2018) [24] (209 mg/L) and Jeremiah et al. (2014) [25] (190.6 mg/L). Moreover, they are greater than the limit values. These differences are thought to be due to the different species of palm nuts, the frequency and the extraction method used (industrial or artisanal). 
Table 1. Characterization of the palm oil mill effluents.

\begin{tabular}{ccccc}
\hline Parameters Values & Units & $\begin{array}{c}\text { Mean } \pm \text { Standard } \\
\text { deviation }\end{array}$ & $\begin{array}{c}\text { Minimum } \\
\text { Values }\end{array}$ & $\begin{array}{c}\text { Maximum } \\
\text { Values }\end{array}$ \\
\hline $\mathrm{T}$ & $\left({ }^{\circ} \mathrm{C}\right)$ & $51.8 \pm 1.74$ & 45 & 60 \\
$\mathrm{pH}$ & $/$ & $4.9 \pm 0.4$ & 4.4 & 5.3 \\
$\mathrm{CND}$ & $\mu \mathrm{S} / \mathrm{cm}$ & $4.6 \pm 0.4$ & 4.1 & 5.2 \\
$\mathrm{SS}$ & $\mathrm{mg} / \mathrm{L}$ & $65,015 \pm 2333.8$ & $30,866.6$ & $82,775.0$ \\
O/F & $\mathrm{mg} / \mathrm{L}$ & $605 \pm 32.5$ & 235 & 800 \\
$\mathrm{COD}$ & $\mathrm{mg} / \mathrm{L}$ & $54,960 \pm 1308.1$ & $46,080.0$ & $71,040.0$ \\
BOD & $\mathrm{mg} / \mathrm{L}$ & $2373.3 \pm 262$ & 760 & 5400 \\
TN & $\mathrm{mg} / \mathrm{L}$ & $2963.3 \pm 248.7$ & 1320 & 5790 \\
TP & $\mathrm{mg} / \mathrm{L}$ & $22,256.6 \pm 1357.4$ & 9500 & 31,270 \\
\hline
\end{tabular}

T: temperature; CND: conductivity; SS: suspended solids; O/F: oil and fat; COD: chemical oxygen demand; BOD: biological oxygen demand; TN: total nitrogen; TP: total phosphorus.

Also, the quantity of water used during the palm oil manufacturing process, the chemical composition of nuts and crude palm oil could also justify these high values as well as the presence of unrecovered palm oil.

\subsection{Screening and Isolation of the Best Purifying Isolate}

28 bacteria isolates revealed the POME purifying character. 5 were selected for further work because of their ability to produce lipolytic enzymes Figure 1.

\subsection{Reduction of Oils and Fats}

Results obtained showed that these bacterial isolates considerably reduced $\mathrm{O} / \mathrm{F}$ within 5 days. In sterile POME samples, the rate of reduction of oils and fats are shown in Figure 2.

Figure 2 shows the $\mathrm{O} / \mathrm{F}$ reduction rates of the isolates during 5 days of incubation in sterile effluent. It emerges from this figure that all these isolates have the capacity to degrade the oils and fats contained in this effluent with the reduction rates of 58.57\% (D11), 61.79\% (D23), 64.88\% (D27), $65.97 \%$ (D22) and $70.81 \%$ (D17). However, isolate D17 is the best purifier of biodegradable organic matter because in its presence we obtain a reduction rate of $70.81 \%$. Similar results were obtained by Jeremiah et al. (2014) during their studies on the biodegradation of POME by bacteria strains revealed that Micrococcus luteus 101PB could reduce oils and fats at the rate of $64.76 \%$, Stenotrophomonas maltophilia $102 \mathrm{~PB}$ at the rate of $67.65 \%$, Bacillus subtilis $106 \mathrm{~PB}$ at the rate of $75.7 \%$ and $\mathrm{Ba}-$ cillus cereus $103 \mathrm{~PB}$ at the rate of $85.14 \%$. The reduction of $\mathrm{O} / \mathrm{F}$ could be due to the fact that these bacteria produces lipolytic enzymes capable of reducing fat into fatty acids that could be absorb by them. 

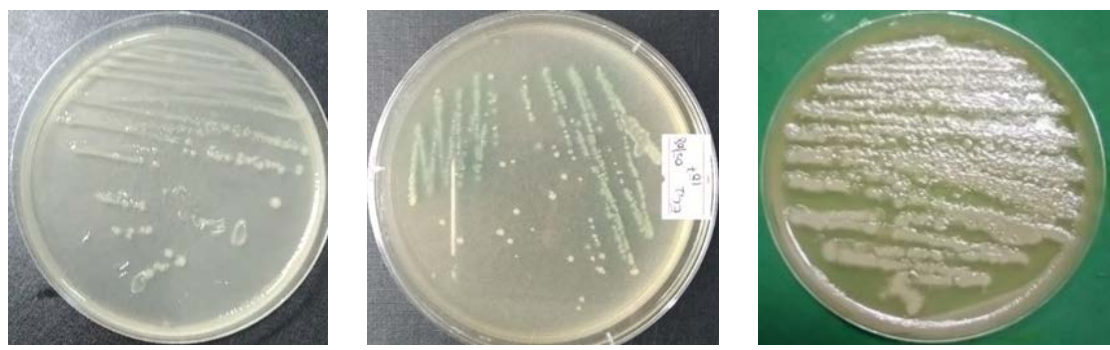

Figure 1. Bacterial isolates from the different samples.

ISOLATES

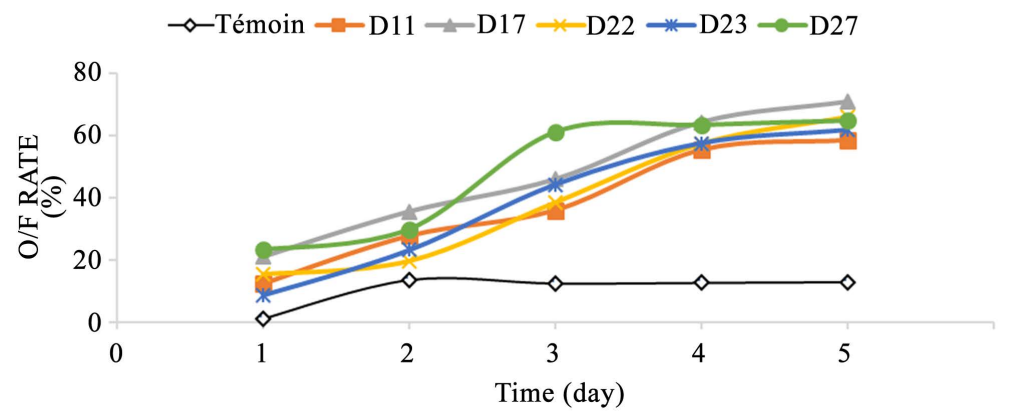

Figure 2. Reduction of Oils and Fats $(\mathrm{O} / \mathrm{F})$.

Logically, the biological treatment of wastewater contaminated with fats significantly reduces the organic load as well as oils and fats [24] [25] [30] [31] [32].

The difference observed in the abatement rates of the different isolates in these studies was due to the different characteristics of the wastewater because the effluents from oil mills each have their own characteristics [33]. Generally, the microbial degradation of oils and fats is the result of the hydrolysis of oils due to a secretion of lipase and/or esterase, which degrade triglycerides into organic acids (fatty acids) and volatile fatty acids then reduce these molecules via beta oxidation (fatty acid degradation pathway).

\subsection{Reduction of COD in the Sterile Effluent}

Figure 3 shows the COD reduction rates of the isolates during 5 days of incubation in sterile effluent. It emerges from this figure that all these isolates have the capacity to degrade the oxidizable organic matter contained in this effluent. The purifying activities of these isolates after 5 days show the reduction rates of 63.92\% (D17), 68.03\% (D11), 76.22\% (D27), 80.82\% (D23), 88.52\% (D22) and $2.59 \%$ for the test sample. This shows that these isolates are effective in reducing COD in sterile POME. They can then be used in biological processes for treating oxidizable organic materials contained in this effluent.

Similar results regarding COD reduction were obtained by Suseela and Muralidhar (2018). In fact, during their work, they obtained COD abatement rates of 80.28\%, 71.08\%, 64.83\%, 61.86\% and 59.26\% respectively from Emericella nidulans, Aspergillus niger, Trichoderma harzianum, Aspergillus fumigatus and Trichoderma reesei. Roux et al. in 2005 reported during their work COD abatement 
rates of $91.3 \%$ by Rhizopus stolonifer, $85.3 \%$ by Penicillium Spp., $84.0 \%$ by $M u$ cor circinelloides $f$. circinelloides and $83.8 \%$ by Aspergillus niger.

The reduction of these pollution parameters is thought to be due to the enzymatic activity exhibited by these isolates. Indeed, they would use these organic materials as a source of energy and carbon necessary for their growth, development and cell synthesis [34]. Also, the abatement rates obtained by these isolates could be explained by the fact that they were isolated from land contaminated by POME and would have adapted to this environment. The biodegradation of oils in the environment is a complex process whose quantitative and qualitative aspects depend on the nature and quantity of oil present, environmental conditions and the constitution of the microbial flora present [25].

\subsection{Partial Characterization of Selected Isolates}

Partial characterization of the best isolates showed that they are all Gram- and Catalase+. Aigbodion et al. (2014) [35] have shown through their studies on the microbial populations of POME and their efficiency in the production of biogas that the Bacillus genera are Gram-, rod-shaped, white in color and produce lipolytic enzymes. So D17 and D23 could belong to the genus Bacillus sp. and D22 to the genus Acinetobacter sp. (Table 2).

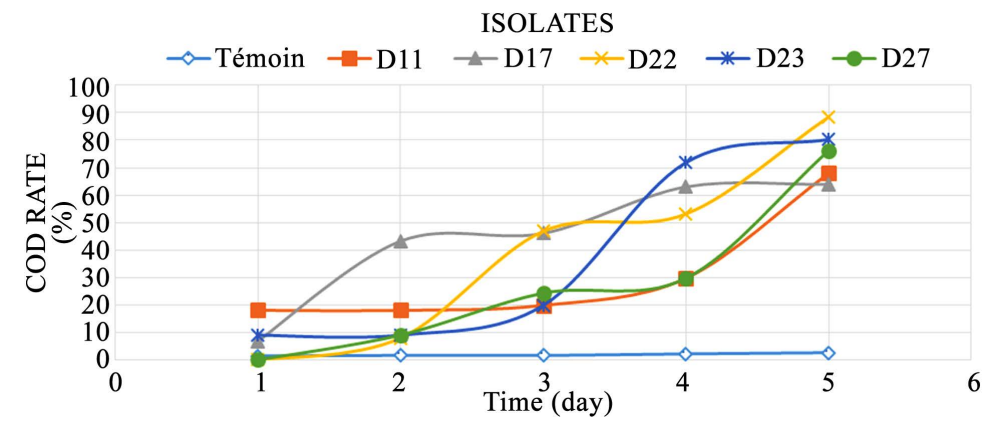

Figure 3. Reduction of Chemical Oxygen Demand (COD).

Table 2. Partial identification of isolates $D 17, D 22$ and $D 13$.

\begin{tabular}{ccccc}
\hline & Characteristics & D17 & D22 & D23 \\
\hline & Colonies & Irregular & Regular & Irregulars \\
Eacroscopic & Edge & regular & regular & Irregulars \\
observations & Areation & Bulging & Bulging & Semi-convex \\
& Color & Brilliant & Brilliant & Rough \\
& Breathing mode & Aerobic & Aerobic & Ahitish \\
$\begin{array}{c}\text { Microscopic } \\
\text { observations }\end{array}$ & Form & Stick & Shell & Stick \\
\hline Miochemical tests & Gram stain & Negative & Negative & Negative \\
\hline
\end{tabular}




\section{Conclusion}

This study revealed that POME is of great capacity of polluting the environment basing on parameters like temperature, $\mathrm{COD}, \mathrm{BOD}, \mathrm{O} / \mathrm{F}, \mathrm{SS}$ and $\mathrm{CND}$. In addition to that, bacteria strains are likely to be used in the bioremediation process because they have a high rate of reducing the polluting parameters. The rates of reducing $\mathrm{O} / \mathrm{F}$ by the retained bacteria strains are ranged from $58.57 \%$ to $70.81 \%$ showing that they could be used in bioremediation to reduce the polluting parameters of POME in Cameroon.

\section{Acknowledgements}

The authors wish to thank his laboratory colleagues for support, researchers of CEREPAH for producing the samples, Dr. NGANGO EBONGUE Georges (head of IRAD branch of Littoral region) for the authorization of the study, and Dr. NSIMI Armand (head of palm oil specialized research) for his technical advice and the concern he had for this study.

\section{Conflicts of Interest}

The authors declare no conflicts of interest regarding the publication of this paper.

\section{References}

[1] Benali, A. and Thame, R.O. (2019) Diagnostic de Fonctionnement de la station d'épuration de Kouinine: Solutions Proposées. Mémoire Université, El Oued, 90 p.

[2] Alexandre, R. (2016) Evaluation de la gestion des eaux usées de l'abattoir d'Etoudi: Impacts environnementaux et sociaux. Mémoire présenté et soutenu en vue de l'obtention du Master Professionnel en Sciences de l'Environnement. Université de Yaoundé I Cameroun, Yaoundé, 80 p.

[3] Noumsi, S. and Tekeu, C. (2001) Dimension industrielle du développement durable au Cameroun: Rapport national et régional au sommet de Rio+10. ONUDI, Yaoundé.

[4] Hasan, F., Alishah, A. and Hameed, A. (2006) Industrial Application of Microbial Lipases. Enzyme and Microbial Technology, 39, 235-251.

https://doi.org/10.1016/j.enzmictec.2005.10.016

[5] Nchanji, Y.K., Tataw, O., Nkongho, R.N. and Levang, P. (2013) Artisanal Milling of Palm Oil in Cameroon. Working Paper 128, CIFOR, Bogor.

[6] Ait Youcef Ilyes (2019) Commandes avancées d'un procédé biologique. Mémoire Université Badji Mokhtar, Annaba, 41 p.

[7] Fiestas Ros Ursinos, J.A., Navarro, G.R., Garcia, A.J. and Maestro, G.M. (1983) Épuration des margines par digestion anaérobie en vue de leur utilisation comme source d'énergie. Valorisation des sous-produits de l'olivier. Rapport. Réunion du Groupe de Travail sur la Valorisation des Sous-Produits de l'Olivier, Madrid (Espagne), 17 novembre 1983, Rome, FAO. (Rapport FAO-AGP-RER/83/002), 131-139.

[8] Achak, A., Ouazzani, N., Yaacoubi, A. and Mandi, L. (2008) Caractérisation des margines issues d'une huilerie moderne et essai de leur traitement par coagulationfloculation par la chaux et le sulfate d'aluminium. Revue des sciences de Peau, 21, 53-57. https://doi.org/10.7202/017930ar 
[9] Jaouani, A., Vanthournhout, M. and Penninckx, M.J. (2005) Olive Oil Mill Wastewater Purification by Combination of Coagulation-Flocculation and Biological Treatments. Environmental Technology, 26, 633-641. https://doi.org/10.1080/09593330.2001.9619503

[10] Inan, I., Dimoglo, A., Simsek, H. and Karpuzcu, M. (2004) Olive Mill Wastewater treatment by Means of Electro-Coagulation. Separation and Purification Technology, 36, 23-31. https://doi.org/10.1016/S1383-5866(03)00148-5

[11] Balice, V., Carrieri, C., Cera, O. and Rindon, B. (1988) The Fate of Tannin-Like Compounds from Olive Mill Effluents in Biological Treatment. In: Hall, E.R. and Hobson, P.N., Eds., Proceedings of the Fifth International Symposium on Anaerobic Digestion, Academic Press, Bologna, 275-280.

[12] Azbar, N., Keskinet, T. and Catalkaya, E.C. (2008) Improvement in Anaerobic Degradation of Olive Mill Effluent (OME) by Chemical Pretreatment Using Batch Systems. The Biochemical Engineering Journal, 38, 379-383.

https://doi.org/10.1016/j.bej.2007.08.005

[13] Hamdi, M. (1992) Toxicity and Biodegradability of Olive Mill Wastewater in Batch Anaerobic Digestion. Applied Biochemistry and Biotechnology, 2, 155-163.

https://doi.org/10.1007/BF02921667

[14] Cañizares, P., Lobato, J., Paz, R., Rodrigo, M.A. and Sáez, C. (2007) Advanced Oxidation Processes for the Treatment of Olive Oil Mills Wastewater. Chemosphere, 67, 832-838. https://doi.org/10.1016/j.chemosphere.2006.10.064

[15] El Hajjouji, H., Barje, F., Pinelli, E., Bailly, J.R., Richard, C., Winterton, P., Revel, J.C. and Hafidi, M. (2008) Photochemical UV/TiO 2 Treatment of Olive Mill Wastewater (OMW). Bioresource Technology, 99, 7264-7269.

https://doi.org/10.1016/j.biortech.2007.12.054

[16] Gernjak, W., Maldonado, M.I., Malato, S., Cáceres, J., Krutzler, T, Glaser, A. and Bauer, R. (2004) Pilot-Plant Treatment of Olive Mill Wastewater (OMW) by Solar $\mathrm{TiO}_{2}$ Photocatalysis and Solar Photo-Fenton. Solar Energy, 77, 567-572. https://doi.org/10.1016/j.solener.2004.03.030

[17] Khoufi, S., Aloui, F. and Sayadi, S. (2006) Treatment of Olive Oil Mill Wastewater by Combined Process Electro-Fenton Reaction and Anaerobic Digestion. Water Research, 40, 2007-2016. https://doi.org/10.1016/j.watres.2006.03.023

[18] Kesse, V. (2016) Evaluation de la gestion des effluents au sein d'une industrie d'extraction d'huile de palme: Cas de Browser plantation (Cameroun). 68 p.

[19] Karima, L. (2009) Méthanisation des boues de la station d'épuration urbaine de Hassi R’mel. Mémoire Pour Obtenir Le Diplôme De Magister. Université De Mostaganem, Algérie, 55.

[20] Ebtesam, E., Mohamed, H.E. and Nawal, E.E. (2005) The Potentiality of Free GramNegative Bacteria for Removing Oil and Grease from Contaminated Industrial Effluents. World Journal of Microbiology \& Biotechnology, 21, 815-822. https://doi.org/10.1007/s11274-004-2239-8

[21] Rodier, J. (2009) L'analyse de l'eau: Eau naturelle, eau résiduaire, eau de mer. 8ème Edition, Dunod Technique, Paris, 709-1033.

[22] Fobasso, T.R., Tavea, F.M., Tetso, G.B., Tchamba, M.M.N., Tcheugoue, S.J., Momo, G. and Etoa, F.X. (2019) Screening and Isolation of Lipase Producing Bacteria from Contaminated Soils from the Littoral-Region of Cameroon and Partial Study of the Fermentation Conditions of the Crude Enzyme Produced. International Journal of Current Microbiology and Applied Sciences, 8, 296-312.

https://doi.org/10.20546/ijcmas.2019.805.035 
[23] Micah, D., Sherpherd, M.K., Kharel, M.A., Bosserman and Jürgen, R. (2010) Laboratory Maintenance of Streptomyces Species. Pubmed Journal, NHI Public Access.

[24] Suseela, L. and Muralidhar, P. (2018) Reduction of Organic Load from Palm Oil Mill Effluent (POME) Using Selected Fungal Strains Isolated from POME Dump Sites. African Journal of Biotechnology, 17, 1138-1145. https://doi.org/10.5897/AJB2016.15821

[25] Jeremiah, D.B., Japareng, L. and Norli, I. (2014) Biodegradation of Palm Oil Mill Effluent (POME) by Bacterial. International Journal of Scientific and Research Publications, 4, 1.

[26] Najafpour, G.D., Zinatizadeh, A.A.L., Mohamed, A.R., Hasnain Isa, M. and Nasrollahzadeh, H. (2006) High-Rate Anaerobic Digestion of Palm Oil Mill Effluent in an Upflow Anaerobic Sludge-Fixed Film Bioreactor. Process Biochemistry, 41, 370-379. https://doi.org/10.1016/j.procbio.2005.06.031

[27] Alhaji, M.H., Sanaullah, K., Lim, S.F., Khan, A., Hipolito, C.N., Abdullah, M.O., Bhawani, S.A. and Jamil, T. (2016) Photocatalytic Treatment Technology for Palm Oil Mill Effluent (POME)-A Review. Process Safety and Environmental Protection, 102, 673-686. https://doi.org/10.1016/j.psep.2016.05.020

[28] Nur, I.H.A., Aziz, M.M. and Hanafiah (2017) The Potential of Palm Oil Mill Effluent (Pome) as a Renewable Energy Source. Acta Scientifica Malaysia, 1, 9-11. https://doi.org/10.26480/asm.02.2017.09.11

[29] AbdulKarim, M.I., Daud, N.A. and Alam, M.D.Z. (2011) Treatment of Palm Oil Mill Effluent Using Microorganisms. In: Alam, M.D.Z., Jameel, A.T. and Amid, A., Eds., Current Research and Development in Biotechnology Engineering at International Islamic University Malaysia (IIUM), Vol. III, IIUM Press, Kuala Lumpur, 269-275.

[30] El-Bestawy, E., El-Masry, M.H. and El-Adl, N.E. (2005) The Potentiality of Free Gram-Negative Bacteria for Removing Oil and Grease from Contaminated Industrial Effluents. World Journal of Microbiology \& Biotechnology, 21, 815-822. https://doi.org/10.1007/s11274-004-2239-8

[31] El-Masry, M.H., El-Bestawy, E. and El-Adl, N.I. (2004) Bioremediation of Vegetable Oil and Grease from Polluted Wastewater Using a Sand Biofilm System. World Journal of Microbiology \& Biotechnology, 20, 551-557. https://doi.org/10.1023/B:WIBI.0000043162.17813.17

[32] Roux-Van der Merwe1, M.P., Badenhorst, J. and Britz, T.J. (2005) Fungal Treatment of an Edible-Oil-Containing Industrial Effluent. World Journal of Microbiology \& Biotechnology, 21, 947-953. https://doi.org/10.1007/s11274-004-6962-y

[33] Ainon, H., Amir, R., Raja, F.H., Raja, A. and Noor, A.Y. (2010) Isolation and Characterization of Bacteria Degrading Sumandak and South Angsi Oils. Sains Malaysiana, 39, 161-168.

[34] Courcol (2018) Physiologie and Croissance; Cours de bactériologie générale; Université LILLE 2.

[35] Aigbodion, A.I., Ogbebor, O.N., Ikhuoria, E.U., Omorogbe, S.O. and Maliki, M. (2014) Microbial Population of Palm Oil Mill Effluent (POME) and Efficiency of Selected Isolates in Biogas Production. Journal of Plantation Crops, 42, 223-227. 